\section{Jack of all trades}

SIR-May I correct an error made in Nature 100 years ago - quoted from Nature 24 July 1890 in Then and Now of 26 July 1990? Your correspondent, J. F., mentioned a large ape said to be acting as a signalman on a railway in Natal. In fact, the ape - a baboon - acted as a railwayman at Uitenhage in the Cape, not in Natal. The story is of some interest and is well-documented.

Mr Wide, a railwayman, had lost both lower legs. He trained a baboon, Jack, to

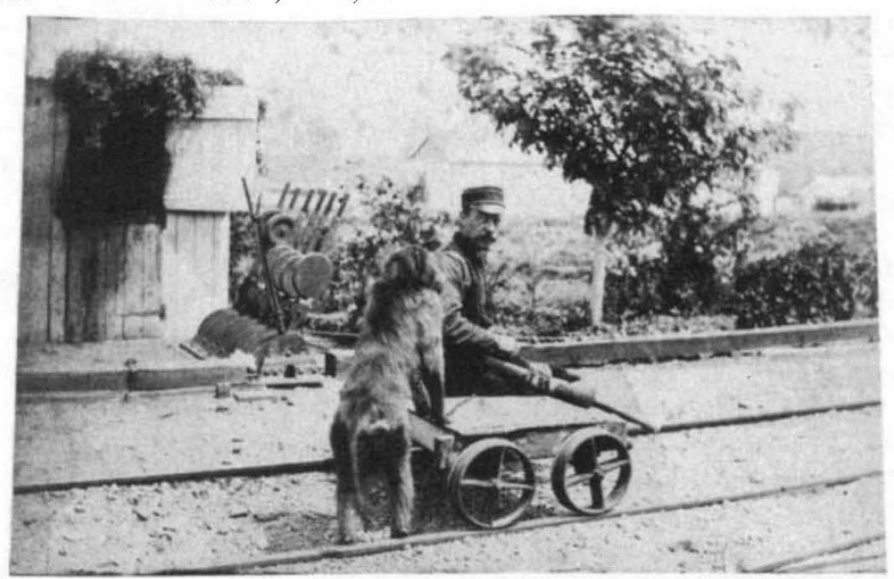

Railway Jack, Wide and their trolley. Initially, Jack pulled the trolley by a chain attached to a hook on Wide's wooden legs, in tandem with a dog. Later the dog was killed by a train and Jack discovered it was easier to push the trolley. The trolley was set on the rails and taken off again by the baboon, twice daily. The control levers are in the background. Photo $c .1890$, collection G. B. Howe.

work the lever of the signals and to carry out various other duties, including pushing Wide to work and back on a trolley which the baboon had to put on the rails (shown in photograph), pumping water, gardening and locking the door. On one occasion, when Wide had injured his arm, Jack took over all his signal-changing duties. According to a reliable witness, "Jack knew every one of the various signals and which lever to pull as well as his master himself". Not unnaturally, the railway passengers objected initially, but "the baboon never failed during his many years of work; and on several occasions he acted in a manner simply astounding to those who have not had personal experience of the high degree of intelligence possessed by these animals". Jack also defended Wide in a quarrel, and on another occasion drove off a foreman by beating him with a dirty coal sack.

$\mathrm{Mr}$ Wide and Jack were extremely close, a relationship expressed by mutual grooming. The story was documented originally by the Rev. George Howe, in 1890 , and then by F. W. Fitzsimons, director of the Port Elizabeth Museum. Fitzsimons'

Letters submitted for Correspondence should be typed, double-spaced, on one side of the paper only. account (of which I have a copy) is published in the Cape Mercury of 29 May 1923. It relies on an interview with Wide, the written statements of 25 witnesses, filed in the museum collection, and on Howe's evidence.

Department of Geology, University of Saskatchewan. Saskatoon

Saskatchewan, S7N OWO. Canada

\section{The value of herbaria}

SIR-As scientists familiar with the chemical and pharmacological study of plants at one of the major pharmacognosy research centres in the United States, we were appalled by the Commentary by Clifford et al. ${ }^{1}$ advocating the dismantling of the world's herbaria. Many criticisms have been published in Correspondence ${ }^{2}$.

One of the most vivid examples of the value of general taxonomic collections comes from a study in the genus Stevia (Asteraceae)". Stevioside, a non-caloric sweetener commercially used in Japan, is extracted from the leaves of the sweettasting plant Stevia vebaudiana (Bertoni) Bertoni. To determine whether other Stevia species contained this compound or related swcet-tasting compounds, we taste-tested small pieces of herbarium speciments of 110 species of Stevia housed in the collections of the Field Museum of Natural History to provide a comprehensive organoleptic survey for the presence of intensely sweet compounds in the genus.

Following the reasoning of Clifford et $a l$., this survey could have been performed by conducting field work to re-collect the 110 Stevia species based on the locality information shown in records of label information: given the commercial interest in non-caloric sweeteners, such funding might have been obtainable. Were such a mission to have succeeded in re-collecting the species, it would have done so at considerable cost.

As it turned out, we found no additional species of Stevia with sweet-testing leaves. Disappointing? Yes, but how much more disappointing to have spent thousands of dollars to have obtained the same result.

Herbaria are vast biological libraries that house information whose future importance we cannot even begin to evaluate. The creativity of nature is much broader than that of humans, and we can ill afford to lose the results of nature's infinitely varied experiments. The folly of destroying libraries of books because they are expensive and because individual accessions are used only intermittently is obvious; the idea of destroying irreplaceable biological libraries is equally absurd.

CHARLOTTE GYLLENHAAL DJAJA DJENDOEL SOEJARTO NORMAN R. FARNSWORTH Program for Collaborative Research in the Pharmaceutical Sciences,

College of Pharmacy,

University of IIlinois.

Chicago,

IIlinois 60680, USA

Michael J. Huft

Missouri Botanical Garden,

St Louis,

Missouri 63166, USA

1. Clifford, H.T., Rogers, R.W. \& Dettman, M.E. Nature 346 $602(1990)$

2. Nature 347, 222-225 (1990)

3. Soejarto, D.D., Kinghorn, A.D. \& Farnsworth, N.R. J. Natural Products 45, 590-599 (1982)

\section{Runaway complexity}

SIR-Here is a teaser that I have never seen adequately addressed: what keeps simple organisms (such as bacteria) staying simple, while other lineages develop extraordinary degrees of morphological complexity? The problem: in general, the more complex the organism, the smaller the population size and therefore the smaller the number of potential selective deaths that can generate further complexity. Is the answer that more complex organisms throw up ever wider ranges of variation on which selection can act, despite smaller populations and ever fewer opportunities for selection events? Is there any particular predisposition in lineages that have 'evolved furthest' or have they just been subject to a sort of runaway complexity?

\section{Department of Geology,}

University of Wales, PO Box 914 ,

Cardiff CF1 3YE, UK 